\title{
Ownership Structure and Firm Financial Performance: Evidence From Panel Data in Sri Lanka
}

\author{
Nirosha Hewa Wellalage and Stuart Locke \\ University of Waikato, New Zealand
}

\begin{abstract}
This study investigates the effects of equity ownership structure on financial performance of Sri Lankan listed businesses. Using dynamic panel generalised method of moment this study finds an inverse hump shape relationship between insider ownership and firm financial performance. The results of this study confirm that the effect of insider ownership on firm performance is more positive and significant where legal protection for investors is weak. It suggests that although new legislative reforms have been enacted, Sri Lankan companies are highly dependent on internal governance mechanisms. There is potential merit in promulgating new rules to control the expropriation of minority shareholders.
\end{abstract}

\section{Keywords}

Ownership structure, financial performance, endogeneity, emerging market, Sri Lanka

\section{Introduction}

This study seeks to determine whether their ownership structure affects Sri Lankan companies' financial performance. Ownership structure is analysed in terms of insider ownership percentage, ownership type (institutional or board) and ownership identity (local or foreign). The impact of ownership on financial performance has been thoroughly explored in the corporate governance literature and the causality linkages between ownership and performance are discussed in traditional agency theory. This may be very important as ownership structure plays a key role in corporate governance, especially in developing countries. The literature indicates that highly concentrated ownership is more widespread in developing economies and developed countries outside the AngloAmerican countries (Shleifer and Vishny 1997; La Porta et al. 1999). In spite of economic and legal differences, almost all Asian companies have concentrated stock ownership reflecting a predominance of family ownership (Chakrabarti 2002).

In Sri Lanka, highly concentrated insider ownership is present in many listed companies and research backs this up. Samarakoon (1999), using listed firms in Sri Lanka, reports share ownership in Sri Lanka is highly concentrated and a small number of shareholders with large shareholdings control a significant portion of voting rights.

Copyright (C) 200x Victoria University. This document has been published as part of the Journal of Business Systems, Governance and Ethics in both online and print formats. Educational and non-profit institutions are granted a nonexclusive licence to utilise this document in whole or in part for personal or classroom use without fee, provided that correct attribution and citation are made and this copyright statement is reproduced. Any other usage is prohibited without the express permission of the publisher. Usually the weakness of investor protection and the absence of well-developed markets for corporate control lead to highly concentrated inside ownership in Sri Lanka. Although this highly concentrated insider ownership reduces the effect of conflicting interests among managers and owners, moral hazard, and adverse selection due to asymmetric information (Christmen et al., 2004), it enhances the managerial entrenchment problem in 
emerging markets.

As a result of the concept of opening the economy, recent tax and tariff exemptions for foreign owners and corporate governance reform activities have attracted foreign investors in Sri Lanka. As a result of these changes, companies in Sri Lanka have high institutional and foreign ownership. An example is the Sri Lankan telecommunication industry: in April 1998, foreign institutional investors owned $61 \%$ of total outstanding shares (Hashim, Munir, \& Khan, 2006). Moreover, similar to other emerging economies, most individual investors' are not willing to invest in emerging markets due to the weak legal protection and uncertainty of the environment. This may be the reason for a high prevalence of institutional ownership in Sri Lanka; Heaw-Wellalage and Locke (2011) stated that institutional ownership is predominant in Sri Lanka, and approximately $95 \%$ of multinational subsidiaries are owned and operated by institutional investors.

Using listed firms in Sri Lanka, this study finds an inverse hump shape relationship between insider ownership and firm financial performance, indicating higher insider ownership increases management entrenchment, and lower insider ownership increases misalignment of the interests of management and owners. Furthermore, the study provides empirical support for the hypothesis that foreign ownership is more efficient than local ownership. This paper adds to the empirical evidence concerning the relationship of ownership structure and firm financial performance regarding insider ownership, ownership type and ownership identity. Moreover, most existing studies use data from the US, UK or other mature markets with high investor protection. Although the role of ownership structure on firm performance has been investigated in South Asia, including Sri Lanka, institutional and foreign ownership effects on firms' financial performance in emerging markets remains unexplored. Hence, it is important to consider how differences in institutional and governance systems between countries may affect the differences in ownership structure and firm value. Furthermore, this paper undertakes the first direct study of firm performance and ownership structure in listed Sri Lankan companies representing all industries except the financial sector. Consequently, the analysis provides a greater robustness than prior research.

The next section reviews prior research and develops the hypotheses. Then there is discussion of the data, variables, method and procedures used for this empirical study. The results and conclusion follow.

\section{Literature Review}

In recent decades research has given increasing attention to the issue of corporate ownership structure and its effect on the financial performance of firms. According to Zeitun and Gary (2007), corporate ownership structure depends on a country's social, political, economic and cultural factors. In an emerging market, these factors are likely to be entirely different from those of developed countries, which may limit the application of empirical models tested in mature markets. Sri Lanka, most Asian countries and some Latin American countries follow emerging market corporate governance mechanisms. The distinguishing features of these economies are that ownership is highly concentrated in the few directors of firms. In such firms, the traditional principal-agent agency conflict is alleviated due to the large shareholders' greater incentives to monitor the manager. However, conflict emerges as large shareholders exercise their substantial control and influence over firm matters and, as agency theory suggests, they have incentives to consume the firm's resources at the expense of the minority shareholders (Anderson and Reeb 2004). This is because an individual or a family will have incentives for both expropriation and monitoring, with a potentially greater incentive for expropriation. Families and individuals are capable of expropriating wealth from the firm through excessive compensation, related-party transactions, or special dividends (Anderson \& Reeb, 2004). While families/individuals may pursue actions that satisfy their own personal goals and happiness, such actions may lead to poor firm performance relative to dispersedly owned firms and impact negatively on the firm's other owners, creating principal-principal agency costs (Anderson \& Reeb, 2004). 


\section{Hypotheses development}

It is now well understood that insider ownership has an important impact on corporate financial performance. One solution to the moral-hazard problem is to give management to shareholders, thereby helping to align managers' and shareholders' interests (Fama and Jensen 1983; Jensen and Meckling 1976). Studies by Ang, Cole and Lin (2000) and Singh and Davidson (2003) confirm higher insider ownership reduces the misalignment between shareholders and managers and lowers agency costs in large US listed firms. McKnight and Weir (2009) find some evidence that higher managerial ownership reduces company agency costs, supporting the earlier findings of Coles, Lemmon and Mescke (2005). This may be because higher personal shareholding by directors bonds them to the company and acts as a method for mitigating agency costs in listed companies. Using 648 German firms, Kaserer and Moldenhauer (2008) also found a positive relationship between insider ownership and stock performance. Insider ownership may improve company performance, because working owners are less inclined to divert resources away from firm value maximisation by decreasing monitoring costs based on the convergence of interest hypothesis (Fama and Jensen 1983; Jensen and Mecking 1976; Shleifer and Vishny 1996). However, an optimal level of insider ownership is determined by firm size, industry, investor protection level, and performance of the firm (Hu and Izumida 2008).

Previous studies find mixed results for insider ownership and company financial performance. A possible explanation for these different results is that some studies were not controlled for the endogeneity of the insider ownership variable and for endogeneity due to fixed effects. Demsetz (1983) and Demsetz and Lehn (1985) argue that insider ownership and company financial value have endogenous effects and that there should be no systematic relationship. However, controlling the endogenous effect of insider ownership and company financial performance, Bohren and Odegaard (2001) find a positive relationship between insider ownership and company value in the Norwegian context. Hence, the first hypothesis, which is formulated regarding insider ownership and financial performance in Sri Lankan listed companies, is:

$\mathrm{H}_{1}$ : Insider ownership has significant positive impact on firm's financial performance.

Lee (2008) considers the Korean context and identified that ownership identity is another important factor in determining firm performance. He explains that due to foreign ownership, some companies have more superior corporate governance mechanisms than local firms, suggesting foreign owned companies may have higher financial performance. Furthermore, using Turkish non-financial firms, Gurbuz and Aybars (2011) find that minority foreign ownership firms' financial performance is superior to locally owned firms in terms of both return on assets and operating profitability. Huang and Shiu (2009) find that foreign ownership is significantly and positively related with firm research and development expenses and contemporaneous and subsequent firm performance. Ferreira and Matos (2008) suggest that foreign institutional ownership is positively associated with firm value and performance outside the US. This may be because foreign ownership brings technology, research and development, and managerial skills. In the South Asian context, Chhibber and Majumdar (1999) found that foreign owned firms display relatively high performance compared to domestic firms. Since the mid-1980s, the Asia region and other emerging markets have been good prospects for direct foreign investments for large multinational companies. Sri Lanka was the earliest South Asian economy to introduce economic reforms to attract foreign investments. The extensive use of foreign capital is high in manufacturing and service sectors in Sri Lanka. Due to the high existence of foreign ownership in the Sri Lankan market, identifying its impact on firm financial performance is important. A second hypothesis regarding ownership identity and financial performance proxies in Sri Lankan listed firms is:

$\mathrm{H}_{2}$ : Foreign ownership is positively associated with firm financial performance.

There is increasing interest in how institutional ownership impacts on corporate governance and firm financial performance, which is associated with the growing volume of equity controlled by 
institutions. Hayashi (2003) shows that in 2003 US, estimated institutional ownership was responsible for $60 \%$ of all outstanding equity in the country, compared to $8 \%$ in 1950 . As a result of the growing volume of equity controlled by institutional owners, the role of institutional investors has changed from passive investors to active monitors. Navissi and Naiker (2006) find institutional owners have greater incentive to monitor management in New Zealand context, and it positively affects firms' financial performance. This may be due to fact that unlike boards of directors, institutional investors have increasingly used their power to pressure managers to come into line with the shareholders' interests (Cornett, Marcus, Saunders, \& Tehranian, 2007). Also, Cornett et al. (2007) explain institutional shareholders have more opportunity, resources and ability to monitor and influence managers. Moreover, higher institutional ownership is always associated with higher board remuneration and incentive-related executive compensation, and it reduces the likelihood of CEO duality on the board (Henry, 2010). Gürbüz, Aybars and Kutlu (2010) analyse 164 firms from the Istanbul Stock Exchange and demonstrate a positive relationship between corporate governance and institutional ownership on firm financial performance. Using 1,914 US companies, Clay (2001) finds a significant positive relationship between company performance and institutional ownership percentage, where a $1 \%$ increase in institutional ownership leads to $0.75 \%$ increase in company financial performance. Similar results were found by Lin (2010) who posits that when the institutional ownership is higher than $81.2 \%$ in Taiwanese companies, firm values start to increase. Hartzell and Starks (2003) find that institutional ownership mitigates agency costs between shareholders and managers, because it increases the monitoring. In line with the above findings, using firms from the North American casino industry, Tasi and Gu (2007) posit a negative agency costs relationship between institutional ownership and agency costs.. Recently, Henry (2010) employed Australian listed companies' data and found similar results.

Prior research provides evidence of four alternative possibilities concerning the relationship between the firm value and institutional ownership, being "efficient monitoring" (Shleifer and Vishny 1997), "cost of capital" (Fama and Jensen 1983), "strategic alignment" and "conflict of interest" (Pound 1988). The efficient monitoring hypothesis provides for a positive relationship between institutional ownership and firm value, while the others indicate a negative relationship. According to the efficient monitoring hypothesis, as shareholders of the company, the institutional owners' primary objective is profit maximisation. In contrast with family or individual owners, institutional owners are multiple owners and can themselves provide clear examples of good or bad corporate governance (Belev, 2003). Hence, institutional owners enhance firm financial performance. Therefore, the third hypothesis regarding ownership type (institutional ownership or board) and financial performance proxies in Sri Lankan listed firms is:

$\mathrm{H}_{3}$ : Institutional ownership is positively associated with firm financial performance

\section{Ownership structure in Sri Lanka}

Corporate governance mechanisms vary around the world and can produce different ownership effects on firm financial performance. Emerging market corporate governance is typically characterised by high insider ownership and a predominance of family ownership. Nevertheless, emerging corporate governance models have not been deeply discussed in corporate governance literature. Masulis, Pham and Zein (2009) study 45 countries and report that family business groups are more predominant in emerging economies. Among that sample, Sri Lanka had the largest family ownership in listed companies at $64 \%$. Emerging markets, where there is concentrated ownership, family ownership and weak legal protection, family members with majority shares are able to engage in window-dressing, tunnelling and expropriate minority shareholders. The concentrated family ownership is the root cause of principal-principal agency problems in Sri Lankan public listed companies. According to Young et al. (2008), there are two main reasons for prevalent inside ownership in emerging economies. The first reason is that founder managed firms are reluctant to share core competences and vital information with outsiders (Zahra and Filatotchev 2004). Weak-legal protection is the second reason for the prevalence of inside ownership in developing countries, including Sri Lanka (Chakrabarti 
2002; La Porta et al. 1997, 1998, 1999, 2000). The underdeveloped nature of financial markets restricts access to external financing and results in family predominant, highly concentrated insider ownership (La Porta et al. 1997, 1998; Pistor et al. 2003). Moreover, consistent with the view of Bolbol, Fatheldin and Omran (2008), the high market uncertainty in Sri Lanka has resulted in companies having high levels of insider ownership, which impacts on corporate governance mechanisms. Almost all the enterprises in Sri Lanka were state-owned (SOEs) in early 1970s. The corporate reform process has brought about a shift from state-owned companies and central planning to a market orientation. The open economy policy was introduced in 1977, and privatisation and restructuring of SOEs has occurred. As a result of these liberalisation activities, public enterprise ownership has switched to private ownership, though ultimately this private ownership has ended up with a few concentrated family owners, individuals and political leaders.

To attract new business, and especially foreign inflow, the Sri Lankan government started free trade zones in the late 1970s. Foreign ownership gradually increased from the early 1980s in Sri Lanka. Compared with the South Asia region, Sri Lanka offered more benefits than India to attract foreign investors. This included $100 \%$ foreign ownership, and the elimination of tariff and quotas. In addition, in the late 1990s, the Sri Lankan Government provided interest free loans of up to 20 million Sri Lankan rupees to start-up businesses in the rural free trade zone. The growth of multinational companies, particularly from 2006 onwards, has resulted in an increased awareness of the foreign ownership in Sri Lanka.

Apart from the foreign ownership, institutional ownership is also highly prevalent in Sri Lankan listed companies. Manawaduge et al. (2009) suggest that a very high percentage of shares on the Sri Lankan stock market are owned by institutional investors. Lee (2010) explains that due to the undeveloped equity market and weak investor protection, domestic investors are reluctant to invest in emerging markets with low levels of corporate governance reform. This may be one reason why foreign institutional ownership is dominant in Sri Lanka. An increase in institutional investor activities in the Sri Lankan share market is positively influenced through sound governance practices.

\section{Data and Methodology}

\section{Sample}

The sample consists of all companies, except financial sector firms, listed on the Colombo Stock Exchange (CSE) over the period 2004 to 2009. Ownership data are drawn from company annual reports and financial data obtained from a CD issued by the CSE. Some listed companies were deleted due to missing. The final sample consisted of 152 companies. Table 1 reports the summary statistics for the sample data. The mean value for insider ownership is $20 \%$, the highest percentage of insider ownership is $81.15 \%$, and the lowest insider ownership representation is 0 . This is consistent with the view that insider ownership of listed companies in Sri Lanka is relatively high. Nevertheless, Bhabra (2007) reports an average insider ownership for her sample of larger New Zealand firms were at $9.34 \%$, and Short and Keasey (1999) report an average insider ownership of $13 \%$ in their UK sample. Overall, companies listed on the CSE have higher insider ownership compared to companies in developed markets. The mean institutional shareholding is $86 \%$. This indicates that a very high percentage of shares on the Sri Lankan stock market are owned by institutional investors. About $56 \%$ of the sample is represented by local firms. This indicates a considerable amount (44\%) of Sri Lankan listed firms are owned and operated by foreign investors. The market based financial performance measure, Tobin's Q, has a mean of 0.57. Compared to developed markets, this mean value of Tobin's $\mathrm{Q}$ is significantly low. However, the return on assets (ROA) mean value is 0.84 ; it indicates CSE listed companies perform well. The control variables, log of sales turnover, leverage and log of firm age are also listed. 
Table 1: Descriptive statistics

\begin{tabular}{|c|c|c|c|c|c|}
\hline Variable & Obs & Mean & Std.dev & Min & Max \\
\hline TOBIN'S Q & $\overline{912}$ & .5728633 & .4912968 & $\overline{-1.470926}$ & 5.371239 \\
\hline ROA & 912 & .844678 & .093799 & 0 & 11.25642 \\
\hline INSIDER & 912 & 19.73784 & 17.32761 & 0 & 81.14924 \\
\hline LNINSIDER & 776 & -.2661282 & 3.486301 & -10.52338 & 4.39620 \\
\hline NIL (INSDIER=0\%) & 912 & .1491228 & .3564049 & 0 & 1 \\
\hline LOW (INSIDER 0-30\%) & 912 & .7434211 & .4369846 & 0 & 1 \\
\hline MEDIUM (INSIDER 30-70\%) & 912 & .0855263 & .2798168 & 0 & 1 \\
\hline HIGH (INSIDER>70) & 912 & .0219298 & & 0 & 1 \\
\hline OWNER (Institutional) & 912 & .8633094 & $\begin{array}{l}.1465348 \\
.3520284\end{array}$ & 0 & 1 \\
\hline LOCAL & 710 & .5611511 & .4369184 & 0 & 1 \\
\hline LNSALES & 912 & 20.3809 & 2.049169 & 14.93163 & 24.78508 \\
\hline DEBT & 912 & .5076976 & .6602301 & -.1422054 & 9.023855 \\
\hline AGE & 912 & 32.99671 & 25.11845 & 3 & 118 \\
\hline LNAGE & 912 & 3.261634 & .6740605 & 1.098612 & 4.770685 \\
\hline INDUSTRY1 & 912 & .0986842 & .2984012 & 0 & 1 \\
\hline INDUSTRY2 & 912 & .3092105 & .4624217 & 0 & 1 \\
\hline INDUSTRY3 & 912 & .0657895 & .2480498 & 0 & 1 \\
\hline INDUSTRY4 & 912 & .3092105 & .4624217 & 0 & 1 \\
\hline INDUSTRY5 & 912 & .2171053 & .4125011 & 0 & 1 \\
\hline
\end{tabular}

\section{Variables}

Financial performance is measured with Tobin's Q and ROA in this study. Since Demsetz and Lehn (1985), most studies use Tobin's Q and ROA to examine the relationship between ownership structure and firm financial performance. Tobin's $Q$ is defined as the market value of a firm divided by the replacement value of its assets. The next performance metric is ROA, calculated as the ratio of the earnings before interest and income tax (EBIT) to total assets, and reflects an accounting based performance measure. Proxies for the ownership structure of the company use three variables. The first is the percentage of shares held by board members, i.e. insider ownership (INSIDER). This variable is further categorised as 4 groups (NIL, LOW, MEDIUM and HIGH) according to the level of insider ownership that exists. The second variable is the dummy variable (OWNER) that takes a value of one when ownership type is institutional and zero otherwise. The third variable is LOCAL, if LOCAL is equal to one when the company has a local owner, otherwise 0 (when company is foreign owned). Similar to previous studies, some control variables are included in the estimated models. Total leverage (DEBT) is measured as the ratio of total debt to total assets and is used as a first control variable in the models. Firm size (LNSALES) accounts for economies of scale, measured by the natural logarithm of total sales. Log of firm age (LNAGE) is also included as a control variable. Based on the industry type, the study divides all firms into five major categories and uses an industry dummy (INDUSTRY) to capture industry-specific characteristics. Appendix 1 provides a glossary of variable definitions. 


\section{Method}

Panel data covering six years of variables for 152 companies is prepared initially. One of the debated issues in recent research is whether or not ownership structure is determined endogenously. Demsetz and Lehn (1995) support an endogenous ownership argument, showing that ownership structure can be determined by firm size, intangibility of profit rate and so forth, concluding that ownership may be endogenous.

The Durbin-Wu-Hausman (DWH) test is used as a diagnostic test for endogeneity of financial performance proxies and other variables. The results of the DWH confirm an endogeneity effect for insider ownership. This finding confirms that ordinary least square (OLS) coefficient estimates will be unreliable and biased. The result of the DWH test for endogeneity suggests that the dynamic panel generalised method of moment (GMM) estimator is preferable.

\section{Results}

Table 2 and Table 3 presents regression results of the dynamic panel GMM estimator with dependent variables (Tobin's $\mathrm{Q}$ and ROA) respectively. The coefficient of INSIDER variable is positively and statistically significant at $1 \%$ level for Tobin's Q and ROA, indicating working owners increase firm financial performance. This is in line with Bhabra (2007), who finds a positive relationship with insider ownership and firm value for New Zealand listed companies. Conceptually, the result is consistent with Jensen and Meckling's (1976) proposed 'convergence of interests' hypothesis, which explains that the manager's value maximisation is an increasing function of insider ownership. Furthermore, as can be seen from Tables 2 and 3, both the higher percentage of insider ownership $(\geq 70 \%)$ and the lowest percentage of insider ownership (0\%) are negatively related to financial performance proxies. This indicates that higher insider ownership increases the problem of management entrenchment and lower insider ownership increases a misalignment of management and owners.

Consideration of the OWNER (institutional ownership or not) variable in Table 3 reveals it is negatively related with ROA at the 5\% significance level, indicating institutional ownership has a negative impact upon Sri Lankan companies' financial performance. However, the institutional ownership variable is not correlated with the Tobin's Q measure of financial performance. This result is in keeping with Lee (2008), who finds an insignificant relationship between institutional ownership of Korean listed companies and Tobin's Q. The ownership identity variable (local or foreign ownership) is significantly negatively related to both financial performance metrics, indicating local ownership negatively impacts on company performance. This is consistent with the Turkish study of Gurbuz and Aybars (2011).

The debt-to-assets ratio is positively related to Tobin's $\mathrm{Q}$ ratio, at $1 \%$ significance level, indicating that with more debt there is a greater increase in company financial performance, although it is insignificant on ROA. The difficulty caused by historical costs assets having low written down values and debt being at market value distorts the numbers and introduces an ageing bias. Furthermore, it can be seen from Tables 2 and 3, firm performance is related to industry type. Firm size has a negative effect on Tobin's $Q$ at 5\% significance level, indicating small firms have higher Tobin's Q than larger firms. On the other hand, firm size is positively related with firm ROA at $1 \%$ significance level, indicating larger firms, perform better than their smaller counterparts. Firm age is positively related to firm financial performance at $1 \%$ significance level, suggesting older firms are more efficient than younger firms.

The auto regressive (AR1) test is reported in Tables 2 and 3, for all variables, detecting no serial correlation order. There is no serial correlation in the original error , as desired. The second specification test also reported at the bottom of Tables 2 and 3 is the overidentification test. The Hansan-Sargan $\mathrm{J}$ statistics are not significant at the 5\% significance level for financial performance metrics, which means that the instruments are valid. 


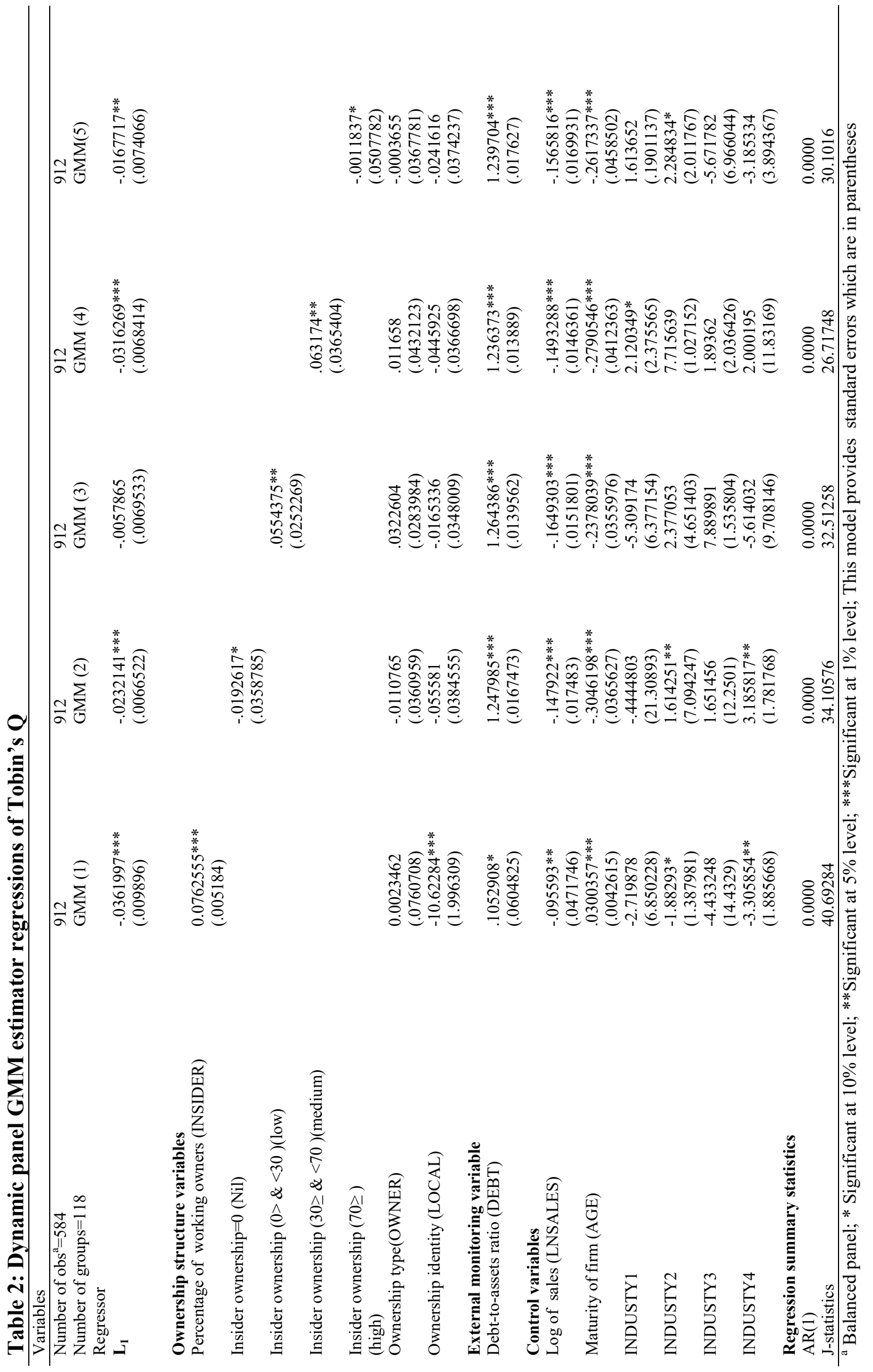




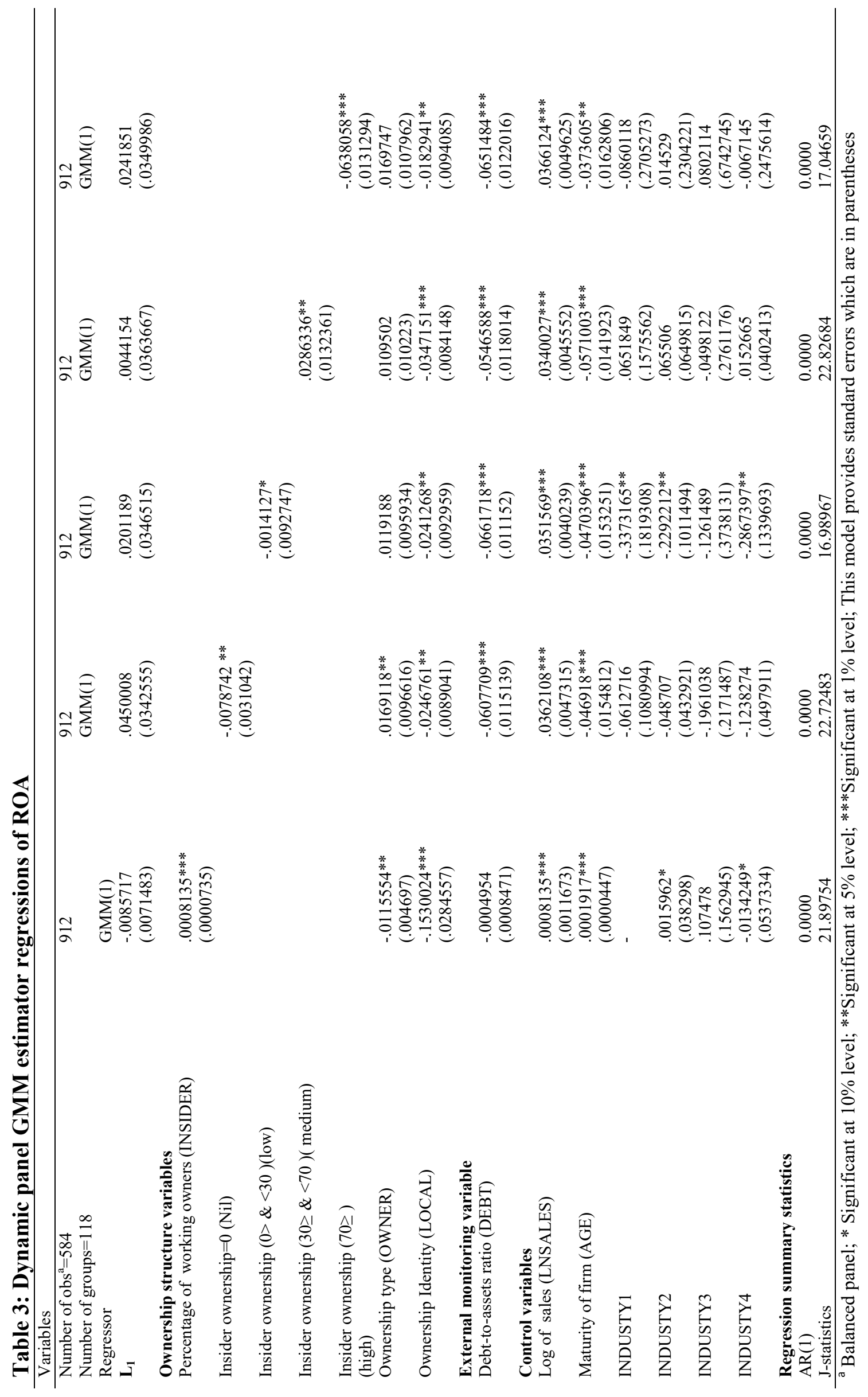




\section{Limitations}

Notwithstanding the findings, the current study does have limitations that point to potentially fruitful further research opportunities. First, this empirical result sheds new light on the importance of ownership structure and firm financial performance, but the current study uses only a few aspects of ownership structure (inside ownership, ownership type and ownership identity). Further studies could consider broader aspects of firm ownership structure. Secondly, the findings are based on research in a single country and may not be generalisable. Further studies in both mature and emerging markets will be helpful in terms of international comparability.

\section{Conclusions}

Using a panel of Sri Lankan listed firms during the period 2004 to 2009, this study examines ownership structure and firm financial performance. The results indicate a significant relationship of insider ownership and financial performance. Furthermore, these findings suggest an inverse U-shape relationship of insider ownership and performance, indicating higher insider ownership increases management entrenchment and lower insider ownership increases misalignment of the interests of management and owners.

The results of this study have important implications for the ownership structure and company performance in Sri Lanka. It confirms that the effect of insider ownership on firm performance is more positive and significant where legal protection for investors is weak. It suggests that although new legislative reforms have been enacted, Sri Lankan companies are highly dependent on internal governance mechanisms. Due to high insider ownership, managerial expropriation is very likely to exist. There is potential merit in promulgating new rules and regulations to control the expropriation of minority shareholders.

The results also point to a significant positive relationship between the companies' Tobin's Q and debt ratio, which indicates firm debt level has significant positive impacts on firm financial performance. This may be due to the fact that the level of debt increases a firm's monitoring by banks, hence reducing agency conflicts. The Sri Lankan debt market is not developed, which is similar to the situation in other developing countries. Corporate debt in Sri Lanka is mainly supplied by the banking sector. Given evidence of the global financial crisis relating to curtailment of bank credit, it is important to enhance fund diversification in Sri Lanka and develop the debt market.

\section{References}

Anderson, C. R., and Reeb, M. D. (2004). Board Composition: Balancing Family Influence in S\&P 500 Firms. Administrative Science Quarterly, 49, 209-237.

Ang, J. S., Cole, R. A., and Lin, J. W. (2000). Agency costs and ownership structure. Journal of Finance, 55, 81-106.

Belev, B. (2003). Institutional Investors in Bulgarian corporate governance reform: obstacles or facilitators. Journal of World Business, 38, 361-374.

Bhabra, G. S. (2007). Insider ownership and firm value in New Zealand. Journal of Multinational financial Management, 17(7).

Bohren, O., and Odegaard, B. A. (2001). Corporate governance and economic performance in Norwegian listed firms. Working Paper.

Bolbol, A., Fatheldin, A., and Omran, M. M. (2008). Corporate governance and firm performance in Arab equity markets: Does ownership concentration matter? International Review of Law and Economics, $28(1)$.

Chakrabarti, R. (2002). Corporate Governance in India - Evolution and Challenges.

Chhibber, Pradeep K., and Sumit K. Majumdar, 1999, Foreign ownership and profitability: Property rights, control, and the performance of firms in Indian industry, Journal of Law and Economics 42, 209-238. 
Chrisman, J. J., Chua, J. H., \& Litz, R. A. (2004). Comparing the Agency Costs of Family and Non-Family Firms: Conceptual Issues and Exploratory Evidence. Entrepreneurship Theory and Practice, 28(4), 335-354.

Clay, D. G. (2001). Institutional Ownership, CEO incentives, and firm value. University of Chicago.

Coles, J., Lemmon, M., and Mescke, J. (2005). Structural models and endogeneity in corporate finance: The link between managerial ownership and corporate performance. Arizona State University working paper.

Cornett, M., Marcus, A., Saunders, A., \& Tehranian, H. (2007). The impact of institutional ownership on corporate operating performance. Journal of Banking \& Finance, 31, 1771-1794.

Demsetz, H. (1983). The structure of ownership and the theory of the firm The Journal of law and economics 26.

Demsetz, H., and Lehn, K. (1985). The Structure of Corporate Ownership: Causes and Consequences. Journal of Political Economy, 93(61).

Fama, E. F., and Jensen, M. C. (1983). Separation of ownership and control. Journal of Law and Economics, 26, 301-325.

Ferreira, M. A., and Matos, P. (2008). The Colors of Investors' Money: The Role of Institutional Investors around the World. Journal of Financial Economics, 88, 499-533.

Gurbuz, A. O., and Aybars, A. (2011). The Impact of Foreign Ownership on Firm Performance, Evidence from an Emerging Market: Turkey. American Journal of Economics and Business Administration, 2(4), 350-359.

Gürbüz, A. O., Aybars, A., and Kutlu, Ö. (2010). Corporate Governance and Financial Performance with a Perspective on Institutional Ownership: Empirical Evidence from Turkey. Journal of Applied Management Accounting Research 8(2).

Hashim, S., Munir, A., and Khan, A. (2006). Foreign Direct Investment in Telecommunication Sector of Pakistan: An Empirical Analysis. Journal of Managerial Sciences, 3(1).

Hartzell, J., \& Starks, L. (2003). Institutional investors and executive compensation. The Journal of Finance, $58(6), 2351-2374$.

Hayashi, A. M. (2003). Effects of Institutional ownership. MIT Salon Management Review, 45(1), 6-7.

Henry, D. (2010). Agency costs, ownership structure and corporate governance compliance: A private contracting perspective. Pacific-Basin Finance Journal, 18, 24-46.

Hu, Y., and Izumida, S. (2008). Ownership Concentration and Corporate Performance: A Causal Analysis with Japanese Corporate Governance: An International Review, 16(4), 342-358.

Huang, R. D., and Shiu, C.-Y. (2009). Local effects of foreign ownership in an emerging financial market: evidence from qualified foreign institutional investors in Taiwan. Autumn. Retrieved from http://findarticles.com/p/articles/mi m4130/is 3 38/ai n39162972/

Jensen, M. C., and Meckling, W. H. (1976). Theory of the Firm: Managerial Behaviour, Agency Costs and Ownership Structure Retrieved from http://papers.ssrn.com/sol3/papers.cfm?abstract id=94043

Kaserer, C., \& Moldenhauer, B. (2008). Insider ownership and corporate performance: evidence from Germany Review of Managerial Science, 2(1), 1-35.

LaPorta, R., Lopez-de-Silanes, F., and Shleifer, A. (1998). Law and finance. Journal of Political Economy, 106(6), 1113-1156.

LaPorta, R., Lopez-De-Silanes, F., and Shleifer, A. (1999). Corporate ownership around the world. Journal of Finance, 54, 471-518.

LaPorta, R., Lopez-de-Silanes, F., Shleifer, A., and Vishny, R. (1997). Legal determinants of external finance. Journal of Finance, 52, 1131-1150.

LaPorta, R., Lopez-de-Silanes, F., Shleifer, A., and Vishny, R. (2000). Investor protection and corporate governance. Journal of Financial Economics, 58(1-2), 3-27.

Lee, J. (2010). Institutional change: Asian corporate governance and finance. Retrieved from http://gdre mbf 2010.u-bordeaux4.fr/sites/gdre mbf 2010/IMG/pdf/lee.pdf

Lee, S. (2008). Ownership structure and financial performance: Evidence from panel data of South Korea. Corporate ownership and Control, 6(2).

Lin, F. (2010). A Panel Threshold Model of Institutional Ownership and Firm Value in Taiwan. International Research Journal of Finance and Economics(42). 
Manawaduge, A., Zoysa, A. D., and Rudkin, K. (2009). Performance implication of ownership structure and ownership concentration: Evidence from Sri Lankan firms. Retrieved from http://www.pma.otago.ac.nz/pma-cd/papers/1040.pdf

Masulis, R. W., Pham, P. K., and Zein, J. (2009). Family Business Groups around the World: Costs and Benefits of Pyramids.

McKnight, P. J., and Weir, C. (2009). Agency costs, corporate governance mechanisms and ownership structure in large UK publicly quoted companies: A panel data analysis. The Quarterly Review of Economics and Finance, 49, 139-158.

Navissi, F., and Naiker, V. (2006). Institutional ownership and corporate value. Managerial Finance, 32(3), 247-256.

Pistor, K., Raiser, M., and Gelfer, S. (2003). Economic Development, Legality and Transplant Effect. European Economic Review, 47(1), 165-195.

Pound, J. (1988). Proxy contests and the efficiency of shareholder oversight. Journal of Financial Economics, 20, 237-265.

Samarakoon, L. P. (1999). The Ownership Structure of Sri Lankan Companies. Sri Lankan Journal of Management, 4, 143-171.

Shleifer, A., and Vishny, R. (1997). A survey of corporate Governance. The Journal of Finance, LII(2).

Short, H., and Keasey, K. (1999). Managerial ownership and the performance of firms: evidence from the U.K. Journal of Corporate Finance, 5, 79-101.

Singh, M., and Davidson, W. N. (2003). Agency costs, ownership structure and corporate governance mechanisms. Journal of Banking and Finance, 27, 793-816.

Tasi, H., \& Gu, Z. (2007). Institutional ownership and firm performance: Empirical evidence from US-Based publicly traded restaurant firms. Journal of Hospitality and Tourism Research, 31(1).

Young, M. N., Peng, M. W., Ahlstrom, D., Bruton, G. D., \& Jiang, Y. (2008). Corporate Governance in Emerging Economies: A Review of the Principal-Principal Perspective. Journal of Management Studies, 45(1), 196-220.

Zahra, S., \& Filatotchev, I. (2004). Governance of the entrepreneurial threshold firm: a knowledge-based perspective. Journal of Management Studies, 41.

Zeitun, R., and Gary, G. T. (2007). Does ownership affect a firm's performance and default risk in Jordan? Corporate Governance: An International Review, 7(1). 


\section{Appendix 1}

\begin{tabular}{|c|c|}
\hline Variable name & Definition \\
\hline \multicolumn{2}{|l|}{ Performance proxies } \\
\hline Tobin's Q & $\begin{array}{l}\text { This ratio is calculated as equity market value plus } \\
\text { liabilities book value divided by equity book value } \\
\text { plus liabilities book value. }\end{array}$ \\
\hline Return on Assets(ROA) & $\begin{array}{l}\text { This ratio is calculated as earned before interest and } \\
\text { taxes divided by total assets }\end{array}$ \\
\hline $\begin{array}{l}\text { Insider Ownership } \\
\text { percentage(INSIDER) }\end{array}$ & $\begin{array}{l}\text { This ratio is calculated as total number of shares } \\
\text { owned by board members divided by issued shares }\end{array}$ \\
\hline Nil & Percentage of working owners $=0$ \\
\hline Low & Percentage of working owners $>0$ and $<30$ \\
\hline Medium & Percentage of working owners $>=30$ and $<70$ \\
\hline High & Percentage of working owners $>=70$ \\
\hline Ownership type (OWNER) & $\begin{array}{l}\text { Dummy variable } 1 \text {, if the ownership type is equal to } \\
\text { institutional ownership }\end{array}$ \\
\hline Ownership identity (LOCAL) & $\begin{array}{l}\text { Dummy variable } 1 \text {, if the ownership identity is equal } \\
\text { to local ownership }\end{array}$ \\
\hline Leverage (bkdbtass) & $\begin{array}{l}\text { This ratio is calculated as total debt divided by total } \\
\text { assets }\end{array}$ \\
\hline \multicolumn{2}{|l|}{ Control variables } \\
\hline lnstaff & Logarithm of number of staff \\
\hline lnage & $\begin{array}{l}\text { Logarithm of number of years operating in the } \\
\text { industry }\end{array}$ \\
\hline Industry 1 & $\begin{array}{l}\text { Dummy variable } 1 \text {, if the industry is equal to } \\
\text { Beverage or Chemical }\end{array}$ \\
\hline Industry 2 & $\begin{array}{l}\text { Dummy variable } 2 \text {, if the industry is equal to health, } \\
\text { hotel, information, stores and supply or service }\end{array}$ \\
\hline Industry 3 & Dummy variable 3 , if the industry is equal to trading \\
\hline Industry 4 & $\begin{array}{l}\text { Dummy variable } 4 \text {, if the industry is equal to land } \\
\text { and property, plantation, palm oil or motor }\end{array}$ \\
\hline Industry5 & $\begin{array}{l}\text { Dummy variable } 5 \text {, if the industry is equal to } \\
\text { manufacturing }\end{array}$ \\
\hline
\end{tabular}


